\title{
KCNC3 ${ }^{\mathrm{R} 42 \mathrm{H}}$, a $\mathrm{K}+$ Channel Mutation Causative in Spinocerebellar Ataxia 13 Displays Aberrant Intracellular Trafficking
}

\author{
Carolina Gallego-Iradi ${ }^{1,3}$, Justin S. Bickford ${ }^{2,3}$, Swati Khare ${ }^{1,3}$, Alexis Hall ${ }^{1,3}$, Jerelyn A. \\ Nick $^{1,3}$, Donya Salmasinia ${ }^{1,3}$, Kolja Wawrowsky ${ }^{4}$, Serguei Bannykh ${ }^{5}$, Duong P. Huynh ${ }^{6}$, \\ Diego E. Rincon-Limas ${ }^{1,3}$, Stefan M. Pulst ${ }^{6}$, Harry S. Nick ${ }^{2,3}$, Pedro Fernandez-Funez ${ }^{1,2,3}$, \\ and Michael F. Waters ${ }^{1,2,3,{ }^{*}}$ \\ ${ }^{1}$ Department of Neurology, College of Medicine, University of Florida, Gainesville, FL 32611, USA \\ ${ }^{2}$ Department of Neuroscience, College of Medicine, University of Florida, Gainesville, FL 32611 , \\ USA \\ ${ }^{3}$ McKnight Brain Institute, College of Medicine, University of Florida, Gainesville, FL 32611, USA \\ ${ }^{4}$ Department of Endocrinology, Cedars-Sinai Medical Center, Los Angeles, CA 90048, USA \\ ${ }^{5}$ Department of Pathology, Cedars-Sinai Medical Center, Los Angeles, CA 90048, USA \\ ${ }^{6}$ Department of Neurology, University of Utah School of Medicine, Salt Lake City, UT 84123, USA
}

\section{Abstract}

Spinocerebellar ataxia 13 (SCA13) is an autosomal dominant disease resulting from mutations in $\mathrm{KCNC} 3$ (Kv3.3), a voltage-gated potassium channel. The $\mathrm{KCNC} 3^{\mathrm{R} 420 \mathrm{H}}$ mutation was first identified as causative for SCA13 in a four-generation Filipino kindred with over 20 affected individuals. Electrophysiological analyses in oocytes previously showed that this mutation did not lead to a functional channel and displayed a dominant negative phenotype. In an effort to identify the molecular basis of this allelic form of SCA13, we first determined that human $\mathrm{KCNC} 3^{\mathrm{WT}}$ and $\mathrm{KCNC} 3{ }^{\mathrm{R} 420 \mathrm{H}}$ display disparate posttranslational modifications, and the mutant protein has reduced complex glycan adducts. Immunohistochemical analyses demonstrated that $\mathrm{KCNC} 3^{\mathrm{R} 420 \mathrm{H}}$ was not properly trafficking to the plasma membrane and surface biotinylation demonstrated that $\mathrm{KCNC}^{\mathrm{R} 420 \mathrm{H}}$ exhibited only $24 \%$ as much surface expression as $\mathrm{KCNC}^{\mathrm{WT}} \cdot \mathrm{KCNC}^{\mathrm{R} 420 \mathrm{H}}$ trafficked through the ER but was retained in the Golgi. $\mathrm{KCNC} 3^{\mathrm{R} 420 \mathrm{H}}$ expression results in altered Golgi and cellular morphology. Electron microscopy of $\mathrm{KCNC} 3^{\mathrm{R} 420 \mathrm{H}}$ localization further supports retention in the Golgi. These results are specific to the $\mathrm{KCNC} 3{ }^{\mathrm{R} 420 \mathrm{H}}$ allele and provide new insight into the molecular basis of disease manifestation in SCA13.

() 2014 Elsevier Inc. All rights reserved

*Corresponding Author: Dr. Michael F. Waters, MD/PhD, Department of Neurology, University of Florida College of Medicine, PO Box 100296, Gainesville, FL 32610, USA mwaters@ neurology.ufl.edu Phone: 352 273-5550, Fax 352 273-5575.

Publisher's Disclaimer: This is a PDF file of an unedited manuscript that has been accepted for publication. As a service to our customers we are providing this early version of the manuscript. The manuscript will undergo copyediting, typesetting, and review of the resulting proof before it is published in its final citable form. Please note that during the production process errors may be discovered which could affect the content, and all legal disclaimers that apply to the journal pertain.

Supplemental Data

Supplemental data include one figure. 


\section{Keywords}

Spinocerebellar ataxia; dominant inheritance; SCA13; KCNC3; voltage-gated potassium channel; Golgi; protein trafficking

\section{Introduction}

The spinocerebellar ataxias (SCAs), a heterogeneous group of neurologic diseases bound by the shared phenotypes of ataxia and motor incoordination, are characterized both by their mode of inheritance and, when known, the particular causative mutation. We previously demonstrated that two different point mutations in the Shaw subtype KCNC3 (Kv3.3) voltage-gated potassium channel located at $19 \mathrm{q} 13.33$ segregate within a four generation Filipino kindred $\left[\mathrm{KCNC} 3^{\mathrm{R} 420 \mathrm{H}}\right.$ (c.1259G $\left.\left.>\mathrm{A}\right)\right]$ and a three generation French pedigree [KCNC3 ${ }^{\mathrm{F} 448 \mathrm{~L}}$ (c.1344C>A)] causing SCA13 (Subramony et al., 2013; Waters et al., 2006). The $\mathrm{KCNC} / \mathrm{Kv} 3$ family contains four related genes (KCNC1/Kv3.1, KCNC2/Kv3.2, KCNC3/ $K v 3.3$, and $K C N C 4 / K v 3.4)$, that can assemble into both homotetrameric and heterotetrameric channels (Chang et al., 2007; Rudy and McBain, 2001). This family of channels has large voltage-dependent $\mathrm{K}^{+}$currents evident upon membrane depolarization at $-20 \mathrm{mV}$, values more positive than any other known mammalian voltage-gated $\mathrm{K}^{+}$channels (Rudy and McBain, 2001).

$\mathrm{KCNC} 3^{\mathrm{R} 420 \mathrm{H}}$ causes a late-onset neurodegenerative phenotype similar to other SCA subtypes, while patients with $\mathrm{KCNC} 3^{\mathrm{F} 448 \mathrm{~L}}$ present with early-onset ataxia accompanied by delayed motor milestones, cognitive delay, and epilepsy. Analyses of the electrophysiological profile for $\mathrm{KCNC} 3^{\mathrm{R} 420 \mathrm{H}}$ in a Xenopus oocyte heterologous system was consistent with a non-functional channel, whereas the $\mathrm{KCNC} 3^{\mathrm{F} 448 \mathrm{~L}}$ mutation altered the gating of KCNC3 thus prolonging the open state (Waters et al., 2006) with these biophysical profiles for these mutants duplicated in the zebra fish $K C N C 3$ genes (Mock et al., 2010). Autosomal dominant inheritance in the Filipino family is characterized by cerebellar signs including gait and limb ataxia, brisk tendon reflexes and mild cognitive impairment (Subramony et al., 2013), as well as abnormal sound localization cueing (Middlebrooks et al., 2013). The most pronounced gross pathological feature in both the Filipino and French kindred was severe, isolated cerebellar atrophy revealed by magnetic resonance (MR) imaging (Subramony et al., 2013; Waters et al., 2006). This pathological hallmark in SCA13, as well as other SCAs is in sharp contrast to the complete lack of alterations in brain anatomy and motor function in any single mouse gene ablation models (Espinosa et al., 2001; McMahon et al., 2004; Zagha et al., 2010) or studies in the zebrafish (Issa et al., 2011; Mock et al., 2010).

We therefore sought to understand the underlying mechanisms that might explain the dominant inheritance of the $K C N C 3^{\mathrm{R} 420 \mathrm{H}}$ allele in SCA13 patients, given that this channel mutation is electrophysiologically non-functional (Mock et al., 2010; Waters et al., 2006). Our studies reveal that $\mathrm{KCNC} 3^{\mathrm{R} 420 \mathrm{H}}$ displays altered post-translational modifications and aberrant intracellular trafficking with associated changes in Golgi and cellular morphology and dominant phenotypes in the Drosophila wing and eye. 


\section{Materials and Methods}

\section{Cell Culture, Transient and Stable Transfection}

COS-1 cells (ATCC, CRL 1650) were cultured in Dulbecco's Modified Eagle's Medium (DMEM, Omega) with 10\% FBS (Omega), $4 \mathrm{mM}$ glutamine, and antibiotic/antimycotic (ABAM) (Gibco) at $37^{\circ} \mathrm{C}$ in humidified air with $5 \% \mathrm{CO}_{2}$. Human neuroblastoma cells, SHSY5Y (ATCC, CRL 2266) were cultured similarly in 1:1 Eagle's Minimum Essential Medium: F12 Medium (ATCC, 30-2003). The human $K C N C 3^{W T}$ cDNA was kindly provided by Dr. James L. Rae (Mayo Foundation) (Rae and Shepard, 2000) and subcloned into pcDNA1 (Invitrogen). $K C N C 3^{W T}$ and individual mutants $\left(K C N C 3^{R 42 O H}\right.$ or $K C N C 3^{F 448 L}$ ) were generated by Quikchange Mutagenesis (Stratagene) and used for transient transfection in COS- 1 cells. For co-transfection, equimolar amounts (1:1) of each plasmid were used. cDNAs for $\mathrm{KCNC} 3^{\mathrm{WT}}, \mathrm{KCNC}^{\mathrm{R} 420 \mathrm{H}}$ or $\mathrm{KCNC}^{\mathrm{F} 448 \mathrm{~L}}$ were subcloned into a pEF-IRES-puro vector for stable selection in SH-SY5Y cells using puromycin and individual colonies selected for clonal expression. Transfections were performed using Lipofectamine LTX (Invitrogen) as per manufacturer's instructions.

\section{Immunoblotting}

Total cellular protein (30 $\mu \mathrm{g}$, Bicinchoninic Acid (BCA) assay (Pierce)) was separated by SDS-PAGE (4-12\% gradient, Invitrogen) and electrotransferred to nitrocellulose membrane (Millipore). The membranes were then blocked for $1 \mathrm{~h}$ with 5\% nonfat dry milk in TBST [10 mM Tris- $\mathrm{HCl}$ (pH 7.5), $200 \mathrm{mM} \mathrm{NaCl}, 0.1 \%$ (v/v) Tween 20] at room temperature. The membranes were incubated overnight at $4{ }^{\circ} \mathrm{C}$ with primary antibodies to KCNC3 (Alomone, APC-102, 1:200) or $\beta 1$ integrin (Chemicon 1952-20, 1:500) washed three times with TBST, incubated with a peroxidase-conjugated secondary antibody for $1 \mathrm{~h}$, washed again three times, and subjected to ECL (Perkin Elmer). To address glycosylation from total cellular protein isolated from SH-SY5Y cells stably expressing $\mathrm{KCNC}^{\mathrm{WT}}$ and $\mathrm{KCNC}^{\mathrm{R}}{ }^{\mathrm{R}} 20 \mathrm{H}$, protein isolates were treated with either PNGase F or Endo H per manufacturer's instructions (New England Biolabs) followed by immunoblot analysis.

\section{Immunohistochemistry}

For immunofluorescence microscopy, transiently transfected COS-1 cells were permeabilized with Dulbecco's PBS containing 0.1\% Triton X-100 for 20 min and blocked with $1 \%$ bovine serum albumin and 5\% goat serum (Sigma) for $1 \mathrm{~h}$. PBS washed cells were incubated with antibodies to KCNC3 (Alomone, APC-102, 1:500), cadherin (Abcam, ab6528, 1:500), calnexin (Abcam, ab2798, 1:200), GM130 (BD Bioscience, 1:200), 58K/ FTCD (Abcam, ab27043,1:50), $\beta$-tubulin (Sigma, T 4026, 1:200) followed by corresponding secondary antibodies conjugated with Alexa Fluor 488 or with Alexa Fluor 568 fluorescent dyes (Molecular Probes). Antigen retrieval was performed in $10 \mathrm{mM}$ sodium citrate and control reactions were devoid of primary antibodies or stained with blocking antibodies. Samples were imaged with a Leica TCS/SP spectral confocal scanner (Leica Microsystems, Mannheim, Germany) in dual emission mode to distinguish autofluorescence from specific staining. 


\section{Membrane Protein Surface Biotinylation}

To study surface localization of membrane proteins, transiently transfected COS-1 cells were subjected to surface biotinylation as per manufacturer's protocols (Cell Surface Protein Isolation Kit, Pierce). Isolated protein was quantified by BCA assay and then subjected to immunoblot analysis for KCNC3 and $\beta 1$ integrin as described above. Densitometry on the resulting immunoblots was performed using ImageJ software (v1.48) to determine the proportion of unmodified to glycosylated proteins for both mutant and WT KCNC3.

\section{Acceptor Photobleaching Fluorescence Resonance Energy Transfer (apFRET)}

COS-1 cells were grown on $1 \mathrm{~cm}$ coverslips and fixed and mounted for processing. Cells transiently transfected with $\mathrm{KCNC} 3{ }^{\mathrm{WT}}$ or $\mathrm{KCNC}^{\mathrm{R} 420 \mathrm{H}}$ were labeled with fluorescently tagged antibodies to KCNC3 (rhodamine, acceptor fluorophore) and GM130 or 58K/FTCD (FITC, donor fluorophore). After $6 \mathrm{~h}$, cells were rinsed in PBS and covered with a thin layer of 50\% PEG solution (Sigma) with gentle rocking for $90 \mathrm{~s}$. The PEG solution was removed by repeated rinses with media and the cells were allowed to recover for $4 \mathrm{~h}$. Pre-bleach images were obtained by laser excitation at $488 \mathrm{~nm}$ (FITC) or $543 \mathrm{~nm}$ (rhodamine). Acceptor bleaching (acceptor) was performed within a region of interest by repeated pulses at $543 \mathrm{~nm}$. A post-bleach FITC (donor) image excited with $543 \mathrm{~nm}$ is also detected. apFRET efficiency was calculated by pixel density as the difference between maximal and absorbed output of the donor (post-bleach minus pre-bleach) divided by the maximal (post-bleach) output of the donor. The data analysis resulted from $\mathrm{n}=9$ for $\mathrm{R} 420 \mathrm{H}, \mathrm{n}=8$ for $\mathrm{WT}$ and $\mathrm{n}=6 \mathrm{~F} 448 \mathrm{~L}$.

\section{Electron Microscopy}

COS- 1 cells transiently transfected with $K C N C 3^{W T}$ and $K C N C 3^{R 42 O H}$ were trypsinized, pelleted, fixed in $1 \%$ osmium tetroxide in $\mathrm{H}_{2} \mathrm{O}$ for $1 \mathrm{~h}$, and then dehydrated with subsequent immersion in 30-100\% acetone and embedded in Eponate (Ted Pella). After overnight polymerization at $56^{\circ} \mathrm{C}$, samples were stained with methylene blue, counterstained with $5 \%$ uranyl acetate in methanol and in Reynold's lead citrate for 10 min each and viewed with a Jeol 100CX transmission electron microscope at $80 \mathrm{kV}$. Digital images were collected with a XR40 Digital Camera (Advance Microscopy Techniques).

\section{Generation of transgenic flies and Drosophila genetics}

The cDNAs encoding $\mathrm{KCNC} 3^{\mathrm{WT}}$ and $\mathrm{KCNC}^{\mathrm{R} 420 \mathrm{H}}$ were first subjected to Quikchange Mutagenesis (Stratagene) to optimize the Kozak sequence for appropriate translation in flies. The $3.2 \mathrm{~kb}$ cDNAs were sub-cloned into the fly expression vector pUAST (Brand and Perrimon, 1993) via EcoRI (5') and NotI (3') ligation. The resulting constructs were sequenced to verify the integrity of the DNAs and injected into $y w$ embryos by standard procedures (Rainbow Transgenics, Inc.). The driver strains $d a$-Gal4 (ubiquitous) and $g m r-$ Gal4 (all eye cells), and the reporter UAS-LacZ were obtained from the Bloomington Drosophila Stock Center. Fly stocks were maintained on standard Drosophila medium at $25^{\circ} \mathrm{C}$. For experiments, homozygous females for the Gal4 strains were crossed with $U A S$ males to generate progeny expressing $\mathrm{KCNC} 3$ in the desired tissue. All crosses were initially placed at $25^{\circ} \mathrm{C}$ for two days and the progeny was raised at $28^{\circ} \mathrm{C}$ to maximize expression. 


\section{Drosophila imaging}

For imaging KCNC3 eyes, targeted eye expression was achieved by crossing gmr-Gal4 females with $\mathrm{KCNC} 3^{\mathrm{WT}}$, $\mathrm{KCNC}^{\mathrm{R} 420 \mathrm{H}}$ and $\mathrm{LacZ}$ flies. Freshly frozen eyes from 1-2 dayold females were imaged as Z-stacks with a Leica Z16 APO using a $2 \times$ Plan-Apo objective and single in-focus images produced with the Montage Multifocus module of the Leica Application Software. For scanning electron microscopy (SEM), flies were serially dehydrated in ethanol, air dried in hexamethyldisilazane (Electron Microscope Sciences), and metal coated for observation in a Hitachi S4000 SEM. The retinal sections were generated by fixing the fly heads in $3 \%$ glutaraldehyde, washed in phosphate buffer, postfixed in 1\% OsO4, dehydrated in ethanol and propylene oxide, embed in Spurr, and subsequently mounted. Blocks were then cut at $1 \mu \mathrm{m}$, stained with toluidine-blue (Fernandez-Funez et al., 2000) and imaged with a plan-apo 63× NA: 1.4 (oil) objective using AxioVision (Zeiss) in an Axio-Observer Z1 microscope (Zeiss). Wings from da-Gal4 females crossed with $\mathrm{KCNC} 3^{\mathrm{WT}}, \mathrm{KCNC}^{\mathrm{R} 420 \mathrm{H}}$ and LacZ flies were collected and kept for two days in a glycerol/ethanol mix. Wings were mounted on slides in the glycerol/ethanol mix, and imaged with a plan-neo 5× NA: 0.16 and a plan-apo $20 \times$ NA: 0.7 objectives using AxioVision as above.

\section{Drosophila Immunoblot Analysis}

For immunoblot analysis of fly protein, $d a-G a l 4$ females were crossed with $\mathrm{KCNC} 3^{\mathrm{WT}}$, $\mathrm{KCNC} 3{ }^{\mathrm{R} 420 \mathrm{H}}$ and LacZ flies. One fly per genotype of 1-2 day-old females was used for this analysis. Single flies were homogenized in $30 \mu$ of RIPA buffer containing complete protease inhibitors (Roche) and centrifuged for $1 \mathrm{~min}$ at 1,000 rpm. Then, $25 \mu \mathrm{L}$ of supernatant was mixed with loading buffer and resolved by SDS-PAGE, transferred to nitrocellulose membrane, immunoblotted, and the signal was revealed by chemiluminescence (Pierce). Anti-KCNC3 (1:4000, Alomone labs) was used to detect KCNC3 with a-tubulin (1:250k, Sigma) as a loading control.

\section{Statistical Analysis}

Quantitative results are given as means \pm SEM. Statistical significance was determined using Student's $t$-test. Values of $\mathrm{p}=0.05$ were considered significant.

\section{Results}

\section{$\mathrm{KCNC}^{\mathrm{R} 420 \mathrm{H}}$ displays altered levels of glycosylation and cellular localization}

Given the lack of an animal model that displays symptoms analogous to the ataxic phenotype observed in SCA13 patients, specifically the later onset, slowly progressive form observed in the Filipino kindred, we assessed both biochemical and cell biological parameters for $\mathrm{KCNC} 3^{\mathrm{R} 420 \mathrm{H}}$ that might explain the fully penetrant autosomal dominant inheritance. We utilized transient transfection of the human $K C N C 3$ constructs in COS-1 cells because of their highly efficient transfection rate. Immunohistochemistry by confocal microscopy of COS-1 cells transiently transfected with $K C N C 3^{W T}$ or $K C N C 3^{R 42 O H}$ reproducibly demonstrated an altered pattern of intracellular localization for $\mathrm{KCNC} 3{ }^{\mathrm{R} 420 \mathrm{H}}$ (Fig. 1A). Expression of $\mathrm{KCNC}^{\mathrm{WT}}$ demonstrated classical membrane protein localization 
with punctate staining of the plasma membrane and distinct perinuclear localization, presumably due to ER and Golgi trafficking of newly synthesized protein. In contrast, $\mathrm{KCNC}^{\mathrm{R}} 420 \mathrm{H}$ showed intense staining in a single perinuclear area that extended out into the cytoplasm with limited staining associated with plasma membrane localization (Fig. 1A).

Protein glycosylation and proper protein folding are associated with the transit of membrane proteins through the endoplasmic reticulum (ER) and the Golgi apparatus. The level of expression for $\mathrm{KCNC} 3^{\mathrm{WT}}$, $\mathrm{KCNC}^{\mathrm{R} 420 \mathrm{H}}$, and $\mathrm{KCNC} 3^{\mathrm{R} 448 \mathrm{~L}}$ were analyzed by immunoblot analysis (Fig. 1B). $\mathrm{KCNC}^{\mathrm{WT}}$ and $\mathrm{KCNC} 3^{\mathrm{R} 448 \mathrm{~L}}$ displayed comparable banding patterns, one at the expected size as well as a slower migrating band. $\mathrm{KCNC}^{\mathrm{R} 420 \mathrm{H}}$, however, showed a diminution of the upper band potentially associated with altered posttranslational modification. $\mathrm{KCNC}^{\mathrm{F} 448 \mathrm{~L}}$ was utilized here and in subsequent experiments since biophysical experiments had implied its normal trafficking to the plasma membrane and as an assurance that observations with $\mathrm{KCNC}^{\mathrm{R} 420 \mathrm{H}}$ were specific to this mutation. As an integral membrane protein, differential centrifugation on the protein isolates was employed to verify that there was no fractional loss of the $\mathrm{KCNC} 3^{\mathrm{R} 420 \mathrm{H}}$ protein within our isolation protocol (Fig. 1C). As in Figure $1 \mathrm{~B}$, the $\mathrm{KCNC} 3^{\mathrm{R} 420 \mathrm{H}}$ protein showed a markedly reduced level of the presumptively post-translationally modified protein. Based on densitometry, the proportion of upper band is $\sim 50 \%$ less for the mutant protein. A dramatic reduction in the upper band for the mutant protein is consistent with observations using different vectors and cell lines (Figs. 1B-D and S1). These representative immunoblots also demonstrate that COS-1 cells do not express endogenous KCNC3 protein.

To verify altered levels of posttranslational modification of $\mathrm{KCNC} 3^{\mathrm{R} 420 \mathrm{H}}$ in a human neuronal cell line, we generated SH-SY5Y stably transfected cells with the empty vector and constructs expressing $\mathrm{KCNC}^{\mathrm{WT}}$ and $\mathrm{KCNC}^{\mathrm{R}} 420 \mathrm{H}$ proteins. As in the COS-1 cells, $\mathrm{SH}-$ SY5Y cells did not express detectable levels of endogenous KCNC3 protein, whereas the cells stably transfected with $\mathrm{KCNC} 3^{\mathrm{WT}}$ showed a similar banding pattern to that observed in COS-1 cells (Fig. 1D). The stable expression of $\mathrm{KCNC}^{\mathrm{R} 420 \mathrm{H}}$ displayed only the lower band, with no detectable upper band. The slower migrating bands detected by the KCNC3 antibody may be the result of various posttranslational modifications. Cartwright et al. (Cartwright et al., 2007) previously showed that Kv3.1-3.4 channels have two highly conserved $N$-glycosylation sites that are likely modified in rat brain by $N$-linked oligosaccharides, one of which is a complex glycan. We therefore utilized endoglycosidase $\mathrm{H}$ (Endo $\mathrm{H}$ ), which cleaves high mannose and some hybrid oligosaccharides of $N$-linked glycoproteins, and peptide- $N$-glycosidase F (PNGase F), which cleaves between the innermost GlcNAc and asparagine residues of high mannose, hybrid, and complex oligosaccharides to investigate the glycosylation pattern. Treatment of cellular extracts from the stably expressing SH-SY5Y cells with Endo H did not affect the upper band but resulted in a faster migrating lower band of both $\mathrm{KCNC} 3^{\mathrm{WT}}$ and $\mathrm{KCNC} 3^{\mathrm{R} 420 \mathrm{H}}$ (Fig. 1E). This small change in migration has been observed in multiple experiments (Fig. S1). In contrast, digestion of cellular extracts with PNGase F resulted in the complete disappearance of the slower migrating upper band and an identical drop in the lower band (Figs. 1E and S1). These results are consistent with modification of $\mathrm{KCNC} 3{ }^{\mathrm{WT}}$ with both complex oligosaccharides and high mannose, whereas $\mathrm{KCNC} 3^{\mathrm{R} 420 \mathrm{H}}$ is only modified by high 
mannose given that both Endo $\mathrm{H}$ and PNGase $\mathrm{F}$ create a slightly faster migrating lower band and the complete absence of the upper band in human neuroblastoma cells.

\section{$\mathrm{KCNC}^{\mathrm{R} 420 \mathrm{H}}$ channel displays limited trafficking to the plasma membrane}

To visualize the cellular distribution of the $\mathrm{KCNC} 3^{\mathrm{WT}}, \mathrm{KCNC}^{\mathrm{F} 448 \mathrm{~L}}$, and $\mathrm{KCNC} 3^{\mathrm{R} 420 \mathrm{H}}$ channel proteins, we investigated the presence of $\mathrm{KCNC} 3$ relative to the plasma membrane protein cadherin. Cadherin co-staining with either $\mathrm{KCNC} 3{ }^{\mathrm{WT}}$ or $\mathrm{KCNC}^{\mathrm{F} 448 \mathrm{~L}}$ showed overlapping surface targeting based on the merged image. The overlapping yellow pixels from the merged image were also visualized as a purple overlay on the KCNC3 image or blue on cadherin, emphasizing the co-registered fluorescence between $\mathrm{KCNC} 3$ and cadherin. $\mathrm{KCNC}^{\mathrm{R} 420 \mathrm{H}}$, in contrast, did not appear to overlap with cadherin at the plasma membrane, again demonstrating that the majority of the mutant protein is intracellular (Fig. 2A).

To further address the impact of altered glycosylation and aberrant trafficking of the mutant channel, surface biotinylation studies were performed. These experiments revealed that the relative level of $\mathrm{KCNC} 3^{\mathrm{R} 420 \mathrm{H}}$ transported to and inserted into the plasma membrane was

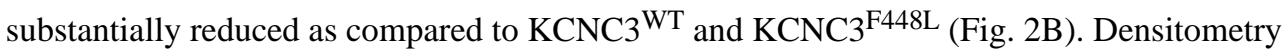
of biotinylated protein normalized to $\mathrm{KCNC} 3^{\mathrm{WT}}$, with the plasma membrane protein $\beta 1$ integrin as a loading control, demonstrated $76 \%$ less surface expression of $\mathrm{KCNC}^{\mathrm{R} 420 \mathrm{H}}$ (Fig. 2C).

\section{$\mathrm{KCNC}^{\mathrm{R} 420 \mathrm{H}}$ channel is retained in the Golgi based on immunohistochemistry}

Integral membrane proteins are normally synthesized and trafficked through the ER and Golgi. We sought to determine which stage of this process might explain the intracellular retention of $\mathrm{KCNC} 3^{\mathrm{R} 420 \mathrm{H}}$. We first compared the transient expression of $\mathrm{KCNC} 3$ to the integral ER membrane chaperone calnexin, which plays a central role in recognizing glycosylated proteins and aiding in protein folding (Moremen et al., 2012). As expected, $\mathrm{KCNC} 3^{\mathrm{WT}}$ exhibits overlap with calnexin in the ER, while the majority of $\mathrm{KCNC} 3^{\mathrm{WT}}$ is detected at the plasma membrane (Fig. 3). In contrast, $\mathrm{KCNC} 3^{\mathrm{R} 420 \mathrm{H}}$ does not co-register with calnexin in the ER, supporting its aberrant trafficking (Fig. 3).

We next investigated $\mathrm{KCNC} 3^{\mathrm{R} 420 \mathrm{H}}$ trafficking by studying its localization in the Golgi apparatus. Transiently expressed $\mathrm{KCNC} 3{ }^{\mathrm{WT}}$ overlaps with the GM130 (Golgi matrix protein of $130 \mathrm{kDa}$ ), a protein associated with the cis-Golgi (Chang et al., 2012) (Fig. 4A).

Immunohistochemical analysis of $\mathrm{KCNC} 3^{\mathrm{R} 420 \mathrm{H}}$ in comparison to $\mathrm{GM} 130$ indicates a partial overlap with the Golgi apparatus (Fig. 4A). To further delineate the Golgi-specific localization of $\mathrm{KCNC} 3^{\mathrm{R} 420 \mathrm{H}}$, we also compared localization of $\mathrm{KCNC} 3$ and $58 \mathrm{~K}$ Golgi protein/formiminotransferase cyclodeaminase (FTCD), an enzyme that couples histidine degradation to folate metabolism and also participates in the interaction of the Golgi complex with the vimentin intermediate filament (IF) cytoskeleton (Gao and Sztul, 2001; Hennig et al., 1998; Mao et al., 2004). As with GM130, KCNC3 ${ }^{\mathrm{WT}}$ overlapped with the $58 \mathrm{~K} / \mathrm{FTCD}$ Golgi marker, with the majority of the protein localized to the plasma membrane at $37^{\circ} \mathrm{C}$ (Fig. 4B). Results on the localization of $\mathrm{KCNC} 3^{\mathrm{R} 420 \mathrm{H}}$ demonstrate a striking overlap with the $58 \mathrm{~K} / \mathrm{FTCD}$ Golgi protein with limited to no expression elsewhere at $37^{\circ} \mathrm{C}$ 
(Fig 4B). Previous studies on the cystic fibrosis transmembrane conductance regulator (CFTR) demonstrated that a mutant form of the protein $(\Delta \mathrm{F} 508)$ exhibiting aberrant trafficking was rescued with proper trafficking to the plasma membrane by growth at $26^{\circ} \mathrm{C}$ (Wilke et al., 2012). We therefore replicated the experiment with $\mathrm{KCNC} 3^{\mathrm{R} 420 \mathrm{H}}$ at $26^{\circ} \mathrm{C}$, however, unlike the results reported for CFTR, the aberrant trafficking of the KCNC3 mutant was not rescued by this growth condition (Fig. 4B).

\section{Fluorescence resonant energy transfer (FRET) demonstrates Golgi localization of $\mathrm{KCNC3}{ }^{\mathrm{R} 42 \mathrm{H}}$}

To extend the immunohistochemical results, FRET was used to demonstrate protein colocalization $(<7 \mathrm{~nm})$. Given the fluorescent co-registration of $\mathrm{KCNC}^{\mathrm{R} 420 \mathrm{H}}$ with Golgispecific proteins with $\mathrm{KCNC} 3^{\mathrm{R} 420 \mathrm{H}}$, acceptor photobleaching fluorescence resonance energy transfer (apFRET) (Day and Davidson, 2012; Day and Schaufele, 2005) was utilized to demonstrate co-localization of KCNC3 with specific regions of the Golgi apparatus. Rhodamine-tagged KCNC3 and FITC-tagged GM130 were used for initial apFRET analysis. Interestingly, both $\mathrm{KCNC} 3{ }^{\mathrm{WT}}$ and $\mathrm{KCNC} 3^{\mathrm{R} 420 \mathrm{H}}$ showed comparable apFRET efficiency, implying that $\mathrm{KCNC}^{\mathrm{R}}{ }^{\mathrm{R} 20 \mathrm{H}}$ was not retained in the cis-Golgi (data not shown). However, a negative FRET result could be due to the positioning of the respective fluorophores and is thus not conclusive. apFRET was further utilized with the FITC-tagged Golgi marker 58K/FTCD in comparison to KCNC3. A representative set of images used for apFRET analysis is provided (Fig. 5A). The apFRET measurements using $\mathrm{KCNC}^{\mathrm{F} 448 \mathrm{~L}}$ and KCNC3 ${ }^{\mathrm{WT}}$ in conjunction with $58 \mathrm{~K} / \mathrm{FTCD}$ demonstrated minimal FRET efficiency, exemplifying the steady-state levels of these proteins in the Golgi due to normal trafficking (Fig. 5B). In contrast, $\mathrm{KCNC}^{\mathrm{R} 420 \mathrm{H}}$ displays a 4-fold greater apFRET efficiency than $\mathrm{KCNC} 3{ }^{\mathrm{WT}}$ or $\mathrm{KCNC} 3^{\mathrm{F} 448 \mathrm{~L}}$ confirming co-localization with $58 \mathrm{~K} / \mathrm{FTCD}$ and retention of $\mathrm{KCNC}^{\mathrm{R} 420 \mathrm{H}}$ in the Golgi (Fig. 5B).

\section{$\mathrm{KCNC}^{\mathrm{R} 420 \mathrm{H}}$ causes subcellular perturbations and alterations in cellular morphology}

Having demonstrated the retention of $\mathrm{KCNC}^{\mathrm{R}} 420 \mathrm{H}$ in the Golgi by various methods, we next sought to further visualize the intracellular localization of this mutant using immunogold transmission electron microscopy (TEM). A high concentration of gold particles (black arrows) is apparent at the phospholipid bilayer and nearby vesicles (grey arrows) in cells expressing $\mathrm{KCNC}^{\mathrm{WT}}$ (Fig. 6A), with minimal intracellular expression or association with clathrin-ordered protein (COP) vesicles (white arrows) (Fig. 6B). These results are consistent with the normal trafficking of a plasma membrane protein. Cells expressing $\mathrm{KCNC} 3{ }^{\mathrm{R} 420 \mathrm{H}}$ display a high concentration of intracellular gold particles associated with a swollen and dysmorphic Golgi structure along with a reduction in the number of COP vesicles (Fig. 6C). Given the observed alterations in Golgi structure, we investigated potential perturbations in gross cytoskeletal structure by $\beta$-tubulin immunohistochemistry in cells expressing $\mathrm{KCNC} 3$. Cells expressing $\mathrm{KCNC} 3^{\mathrm{R} 420 \mathrm{H}}$ displayed altered cellular morphology relative to cells expressing $\mathrm{KCNC}_{3}{ }^{\mathrm{WT}}$ (Fig. 6D), consistent with many of the other representative images of $\mathrm{KCNC}^{\mathrm{R} 420 \mathrm{H}_{-}}$-expressing cells (Figs. 1, 2, and 4). 


\section{Effect of co-transfection of $\mathrm{KCNC}^{\mathrm{WT}}$ and $\mathrm{KCNC} 3^{\mathrm{R} 420 \mathrm{H}}$}

It has been previously reported that co-expression of $\mathrm{KCNC} 3{ }^{\mathrm{WT}}$ and $\mathrm{KCNC} 3^{\mathrm{R} 420 \mathrm{H}}$ results in channels displaying a $\sim 90 \%$ reduction in normalized peak current amplitudes at $+60 \mathrm{mV}$ (Minassian et al., 2012; Waters et al., 2006). However, these studies did not address channel formation or membrane localization. To address co-expression analogous to previous studies, we repeated our immunohistochemical studies using transient transfection at a 1:1 ratio of $\mathrm{KCNC} 3^{\mathrm{WT}}: \mathrm{KCNC} 3^{\mathrm{R} 420 \mathrm{H}}$. Combined expression of these proteins resulted in little to no surface expression of $\mathrm{KCNC} 3$ when compared to staining for the surface protein cadherin (Fig. 7). Having demonstrated the retention of $\mathrm{KCNC}^{\mathrm{R}} 420 \mathrm{H}$ alone in the Golgi (Figs. 4, 5, and $6 \mathrm{~A}-\mathrm{C}$ ), we also sought to determine if the $\mathrm{KCNC} 3^{\mathrm{R} 420 \mathrm{H}}$ protein could cause retention of $\mathrm{KCNC} 3^{\mathrm{WT}}$ in the Golgi. As shown in Figure 7, the majority of the $\mathrm{KCNC} 3$ in the cotransfected cells co-registers with the Golgi marker 58K/FTCD by immunohistochemical analysis, implying that either the mutant protein sequesters $\mathrm{KCNC} 3{ }^{\mathrm{WT}}$ through direct interaction or $\mathrm{KCNC} 3^{\mathrm{R} 420 \mathrm{H}}$ disrupts a trafficking pathway specific to $\mathrm{KCNC} 3$. This latter argument is based on the normal trafficking of cadherin (Figs. 2 and 7, top) and $\beta$-integrin (Fig. 2B) in spite of $\mathrm{KCNC}^{2}{ }^{\mathrm{R}} 20 \mathrm{H}$ expression. This experiment is limited in that the two proteins cannot be identified separately, given only a single amino acid difference. However as with other co-transfection experiments, such as in the generation of iPS cells or cell lines for the production of virus, the co-expression from multiple plasmids in the same cell is well demonstrated. In addition, the images (Fig. 7) also illustrate an altered cellular morphology in cells expressing a SCA13 patient-relevant 1:1 ratio of mutant to $\mathrm{KCNC}^{\mathrm{WT}}$ protein.

\section{$\mathrm{KCNC}^{\mathrm{R} 420 \mathrm{H}}$ perturbs wing and eye development in Drosophila melanogaster}

As discussed, no animal model-based studies have demonstrated morphological changes resulting from $\mathrm{KCNC}^{\mathrm{R} 420 \mathrm{H}}$ expression. Having established cellular alterations resulting from expression of the mutant protein, we sought to determine whether these disruptions affect cells in the complex cellular environment of intact tissues and organs. For this, we generated transgenic Drosophila melanogaster carrying human $K C N C 3^{W T}$ or $K C N C 3^{R 420 H}$ under the control of the UAS/Gal4 expression system (Brand and Perrimon, 1993) by crossing with flies carrying the ubiquitous daughterless-Gal4 (da-Gal4) driver. To examine protein expression levels, protein homogenates from whole flies expressing LacZ, $\mathrm{KCNC} 3{ }^{\mathrm{WT}}$ and $\mathrm{KCNC} 3{ }^{\mathrm{R} 420 \mathrm{H}}$ were assayed by immunoblot analysis for $\mathrm{KCNC} 3$ protein. In control flies expressing LacZ, we detected no signal with the mammalian KCNC3 antibody. Flies expressing either $\mathrm{KCNC} 3^{\mathrm{WT}}$ or $\mathrm{KCNC} 3^{\mathrm{R} 420 \mathrm{H}}$ produced specific immunoreactivity at the expected molecular weight with comparable expression levels (Fig. 8A).

The Drosophila wing consists of a simple epithelium folded onto itself with characteristic size and shape. The wing also contains robust pattern elements, including the sensory elements in the wing margin and the veins inside the wing. Expression of LacZ or $\mathrm{KCNC} 3^{\mathrm{WT}}$ under the control of $d a-G a l 4$ resulted in wings with normal size and shape and normal veins (Fig. 8B). However, expression of $\mathrm{KCNC}^{\mathrm{R} 420 \mathrm{H}}$ resulted in abnormal wing vein development, including the loss of the anterior cross vein (ACV), thickening of longitudinal veins L2 and L3, a distorted posterior cross vein (PCV) and partial loss of L5 (Fig. 8B, red arrows). These alterations in vein patterning resemble changes observed in signaling pathways implicated in wing growth and patterning (Price et al., 1997). 
To address the consequences of targeted $\mathrm{KCNC}^{\mathrm{R} 420 \mathrm{H}}$ expression, we used the gmr-Gal4 driver to achieve specific expression in all differentiating eye cells, including photoreceptors and other support cells. The Drosophila eye consists of 800 ommatidia neatly organized in a lattice that is easily disorganized by perturbations in genes and pathways involved in the specification of photoreceptors and the recruitment of accessory cells. Images from fresh eyes illustrate no gross changes in eye morphology (Fig. 8C, top row). Flies expressing LacZ or $\mathrm{KCNC}^{\mathrm{WT}}$ produced eyes with normal ommatidia and lattice structure (Fig. 8C). In contrast, expression of $\mathrm{KCNC}^{\mathrm{R} 420 \mathrm{H}}$ resulted in small perturbations of the eye, including multiple fused ommatidia and disruption of the normal lattice organization (Fig. 8C, SEM). Each ommatidium contains eight precisely organized photoreceptor cells, although only seven are visible due to the stacking of R7 and R8 (Fig. 8C, inset, bottom row). Sectioning these eyes to uncover the arrangement of photoreceptor cells within each ommatidium revealed that expression of $\mathrm{LacZ}$ or $\mathrm{KCNC} 3^{\mathrm{WT}}$ did not perturb the differentiation or organization of the photoreceptor cells (Fig. 8C, bottom row). Expression of $\mathrm{KCNC} 3{ }^{\mathrm{R}} 420 \mathrm{H}$, however, caused aberrant differentiation of photoreceptor cells (Fig. 8C, bottom row, yellow arrowheads) and abnormal cell polarity (red lines). These phenotypes are consistent with the alterations in wing patterning, suggesting that $\mathrm{KCNC} 3^{\mathrm{R} 420 \mathrm{H}}$ affects key signaling pathways in both tissues.

\section{Discussion}

SCA13 is an autosomal dominant disease and, as such, expression of the $K C N C 3^{R 42 O H}$ allele is causative in the presence of the $K C N C 3^{W T}$ allele. Studies in Xenopus oocytes and zebrafish (Issa et al., 2011; Minassian et al., 2012; Mock et al., 2010; Zhao et al., 2013) have implicated dominant negative effects of $\mathrm{KCNC} 3^{\mathrm{R} 420 \mathrm{H}}$ based on electrophysiological studies demonstrating the lack of channel activity in heterologous systems. However, evidence for the underlying molecular basis of disease is lacking. Zhao et al. (Zhao et al., 2013) recently attempted to address this by illustrating both a reduction in protein half-life and cell surface expression for $\mathrm{KCNC} 3{ }^{\mathrm{R} 420 \mathrm{H}}$ overexpressed in $\mathrm{CHO}$ cells. These phenomena were attributed to increased protein degradation. It is, however, counterintuitive that reduced protein levels of $\mathrm{KCNC} 3{ }^{\mathrm{R} 420 \mathrm{H}}$ would be causative in a dominantly inherited disease. Our results, however, demonstrate that $\mathrm{KCNC} 3^{\mathrm{R} 420 \mathrm{H}}$ displays aberrant glycosylation and trafficking with a significant reduction in surface expression in conjunction with altered Golgi and cellular morphology. Furthermore, expression of the human $\mathrm{KCNC}^{\mathrm{R} 420 \mathrm{H}}$ during the life cycle of Drosophila results in developmental abnormalities of both wing and eye.

To address biochemical or cellular alterations associated with $\mathrm{KCNC} 3^{\mathrm{R} 420 \mathrm{H}}$ expression, we demonstrated an altered pattern of glycosylation similar to the previous characterization of $\mathrm{KCNC} 3{ }^{\mathrm{WT}}$ glycan modifications (Cartwright et al., 2007). Enzymatic digestion of $\mathrm{KCNC} 3^{\mathrm{WT}}$ by PNGase $\mathrm{F}$ removes both complex carbohydrate and high mannose modifications, whereas Endo $\mathrm{H}$ treatment of cellular extracts only removes high mannose modifications, implying that $\mathrm{KCNC} 3{ }^{\mathrm{WT}}$ exists with both types of carbohydrate moieties. In contrast, $\mathrm{KCNC} 3{ }^{\mathrm{R} 420 \mathrm{H}}$ lacks the complex carbohydrate modifications but may possess high mannose chains based on a small increase in protein mobility following treatment with either Endo H or PNGase F. 
Given these results, we also studied the intracellular localization and trafficking of both $\mathrm{KCNC}^{\mathrm{WT}}$ and $\mathrm{KCNC} 3^{\mathrm{R} 420 \mathrm{H}}$ and were able to demonstrate that $\mathrm{KCNC}^{\mathrm{R} 420 \mathrm{H}}$ was retained in an intracellular compartment with a limited presence at the plasma membrane. The markedly reduced trafficking of $\mathrm{KCNC} 3^{\mathrm{R} 420 \mathrm{H}}$ to the plasma membrane was confirmed by surface biotinylation and the lack of co-registration with cadherin at the membrane. Further characterization of trafficking suggests that $\mathrm{KCNC} 3^{\mathrm{R} 420 \mathrm{H}}$ traverses the endoplasmic reticulum. Immunohistochemical results indicate that $\mathrm{KCNC} 3{ }^{\mathrm{R}} 420 \mathrm{H}$ co-registers with both the cis-Golgi marker GM130 and 58K/FTCD whereas apFRET data specifically demonstrated co-localization with the 58K/FTCD Golgi protein. Bloom and Brashear's characterization of 58K/FTCD described it as a peripheral membrane protein exposed to the cytoplasmic side of the Golgi, directly interacting with the microtubule network (Bloom and Brashear, 1989). Gao and Sztul further demonstrated that 58K/FTCD specifically interacts with the Golgi membrane and vimentin filaments proximal to the Golgi (Gao and Sztul, 2001). Therefore, our immunohistochemistry and apFRET data indicate that $\mathrm{KCNC} 3{ }^{\mathrm{R}} 420 \mathrm{H}$ is retained in the Golgi membranes, unlike cadherin and $\beta$-integrin which traffic normally to the plasma membrane even in cells expressing $\mathrm{KCNC} 3^{\mathrm{R} 420 \mathrm{H}}$. The retention of $\mathrm{KCNC} 3^{\mathrm{R}} 420 \mathrm{H}$ in the Golgi also appears to affect the integrity of the Golgi apparatus based on EM and cellular morphology as illustrated by $\beta$-tubulin co-staining.

In simulating the natural existence of both a wild-type and mutant allele in SCA13 patients, co-expression of $\mathrm{KCNC} 3{ }^{\mathrm{WT}}$ and $\mathrm{KCNC} 3^{\mathrm{R} 420 \mathrm{H}}$ appears to inhibit surface expression of $\mathrm{KCNC}{ }^{\mathrm{WT}}$ with Golgi retention of both proteins comparable to $\mathrm{KCNC} 3^{\mathrm{R} 420 \mathrm{H}}$ alone. At the cellular level, this may explain how $\mathrm{KCNC} 3^{\mathrm{R} 420 \mathrm{H}}$ contributes to the autosomal dominant inheritance causative in SCA13 patients. The morphological alterations induced by expression of $\mathrm{KCNC} 3^{\mathrm{R} 420 \mathrm{H}}$ in the wing and eye during Drosophila development also provide insights into phenotypic impacts in a complex cellular environment. Our current efforts are therefore focused on the development of a mouse model that directly mimics autosomal dominant inheritance in SCA13.

In summary, we have demonstrated that a mutation that is causative for SCA13, $\mathrm{KCNC} 3^{\mathrm{R} 420 \mathrm{H}}$, exhibits altered glycosylation coupled with aberrant trafficking with a significant fraction of the protein retained in the Golgi. The cellular consequences of this retention are altered Golgi and cellular morphology. Most relevant is the observation that co-expression of $\mathrm{KCNC} 3{ }^{\mathrm{WT}}$ and $\mathrm{KCNC} 3{ }^{\mathrm{R} 420 \mathrm{H}}$, analogous to a heterozygote genotype, results in co-retention of both proteins. The latter result provides a rationale for disease manifestation in SCA13.

\section{Supplementary Material}

Refer to Web version on PubMed Central for supplementary material.

\section{Acknowledgments}

The authors would like to thank Daniela Arbelaez and Praneetha Muthumani for their technical assistance in completing this work. Support provided, in part, by NIH NINDS K23 NS054715 (MFW), the McKnight Brain Institute, and the Rosalyn Heilman Research Foundation. 


\section{References}

Bloom GS, Brashear TA. A novel 58-kDa protein associates with the Golgi apparatus and microtubules. J Biol Chem. 1989; 264:16083-92. [PubMed: 2777777]

Brand AH, Perrimon N. Targeted gene expression as a means of altering cell fates and generating dominant phenotypes. Development. 1993; 118:401-15. [PubMed: 8223268]

Carlson KM, et al. Emerging pathogenic pathways in the spinocerebellar ataxias. Curr Opin Genet Dev. 2009; 19:247-53. [PubMed: 19345087]

Cartwright TA, et al. Complex oligosaccharides are N-linked to Kv3 voltage-gated $\mathrm{K}+$ channels in rat brain. Biochim Biophys Acta. 2007; 1770:666-71. [PubMed: 17197096]

Chang SH, et al. GOLGA2/GM130, cis-Golgi matrix protein, is a novel target of anticancer gene therapy. Mol Ther. 2012; 20:2052-63. [PubMed: 22735382]

Chang SY, et al. Distribution of Kv3.3 potassium channel subunits in distinct neuronal populations of mouse brain. J Comp Neurol. 2007; 502:953-72. [PubMed: 17444489]

Day RN, Davidson MW. Fluorescent proteins for FRET microscopy: monitoring protein interactions in living cells. Bioessays. 2012; 34:341-50. [PubMed: 22396229]

Day RN, Schaufele F. Imaging molecular interactions in living cells. Mol Endocrinol. 2005; 19:167586. [PubMed: 15761028]

Espinosa F, et al. Alcohol hypersensitivity, increased locomotion, and spontaneous myoclonus in mice lacking the potassium channels Kv3.1 and Kv3.3. J Neurosci. 2001; 21:6657-65. [PubMed: 11517255]

Fernandez-Funez P, et al. Identification of genes that modify ataxin-1-induced neurodegeneration. Nature. 2000; 408:101-6. [PubMed: 11081516]

Fowler PW, Sansom MS. The pore of voltage-gated potassium ion channels is strained when closed. Nat Commun. 2013; 4:1872. [PubMed: 23695666]

Gao Y, Sztul E. A novel interaction of the Golgi complex with the vimentin intermediate filament cytoskeleton. J Cell Biol. 2001; 152:877-94. [PubMed: 11238446]

Goldman-Wohl DS, et al. Kv3.3b: a novel Shaw type potassium channel expressed in terminally differentiated cerebellar Purkinje cells and deep cerebellar nuclei. J Neurosci. 1994; 14:511-22. [PubMed: 8301351]

Harding AE. The clinical features and classification of the late onset autosomal dominant cerebellar ataxias. A study of 11 families, including descendants of the 'the Drew family of Walworth'. Brain. 1982; 105:1-28. [PubMed: 7066668]

Hennig D, et al. A formiminotransferase cyclodeaminase isoform is localized to the Golgi complex and can mediate interaction of trans-Golgi network-derived vesicles with microtubules. J Biol Chem. 1998; 273:19602-11. [PubMed: 9677386]

Issa FA, et al. Spinocerebellar ataxia type 13 mutant potassium channel alters neuronal excitability and causes locomotor deficits in zebrafish. J Neurosci. 2011; 31:6831-41. [PubMed: 21543613]

Joho RH, Hurlock EC. The role of Kv3-type potassium channels in cerebellar physiology and behavior. Cerebellum. 2009; 8:323-33. [PubMed: 19247732]

Long SB, et al. Atomic structure of a voltage-dependent $\mathrm{K}+$ channel in a lipid membrane-like environment. Nature. 2007; 450:376-82. [PubMed: 18004376]

Mao Y, et al. Structure of the bifunctional and Golgi-associated formiminotransferase cyclodeaminase octamer. EMBO J. 2004; 23:2963-71. [PubMed: 15272307]

McMahon A, et al. Allele-dependent changes of olivocerebellar circuit properties in the absence of the voltage-gated potassium channels Kv3.1 and Kv3.3. Eur J Neurosci. 2004; 19:3317-27. [PubMed: 15217387]

Middlebrooks JC, et al. Mutation in the kv3.3 voltage-gated potassium channel causing spinocerebellar ataxia 13 disrupts sound-localization mechanisms. PLoS One. 2013; 8:e76749. [PubMed: 24116147]

Minassian NA, et al. Altered Kv3.3 channel gating in early-onset spinocerebellar ataxia type 13. J Physiol. 2012; 590:1599-614. [PubMed: 22289912] 
Mock AF, et al. Functional effects of spinocerebellar ataxia type 13 mutations are conserved in zebrafish Kv3.3 channels. BMC Neurosci. 2010; 11:99. [PubMed: 20712895]

Moremen KW, et al. Vertebrate protein glycosylation: diversity, synthesis and function. Nat Rev Mol Cell Biol. 2012; 13:448-62. [PubMed: 22722607]

Price JV, et al. Dominant enhancers of Egfr in Drosophila melanogaster: genetic links between the Notch and Egfr signaling pathways. Genetics. 1997; 147:1139-53. [PubMed: 9383058]

Rae JL, Shepard AR. Kv3.3 potassium channels in lens epithelium and corneal endothelium. Exp Eye Res. 2000; 70:339-48. [PubMed: 10712820]

Reeber SL, et al. Architecture and development of olivocerebellar circuit topography. Front Neural Circuits. 2012; 6:115. [PubMed: 23293588]

Rudy B, McBain CJ. Kv3 channels: voltage-gated K+ channels designed for high-frequency repetitive firing. Trends Neurosci. 2001; 24:517-26. [PubMed: 11506885]

Subramony SH, et al. Comprehensive phenotype of the p.Arg420his allelic form of spinocerebellar ataxia type 13. Cerebellum. 2013; 12:932-6. [PubMed: 23912307]

Waters MF, et al. Mutations in voltage-gated potassium channel KCNC3 cause degenerative and developmental central nervous system phenotypes. Nat Genet. 2006; 38:447-51. [PubMed: 16501573]

Waters MF, Pulst SM. Sca13. Cerebellum. 2008; 7:165-9. [PubMed: 18592334]

Weiser M, et al. Differential expression of Shaw-related K+ channels in the rat central nervous system. J Neurosci. 1994; 14:949-72. [PubMed: 8120636]

Wilke M, et al. Rescue of murine F508del CFTR activity in native intestine by low temperature and proteasome inhibitors. PLoS One. 2012; 7:e52070. [PubMed: 23284872]

Zagha E, et al. Dendritic Kv3.3 potassium channels in cerebellar purkinje cells regulate generation and spatial dynamics of dendritic Ca2+ spikes. J Neurophysiol. 2010; 103:3516-25. [PubMed: 20357073]

Zhao J, et al. Spinocerebellar ataxia-13 Kv3.3 potassium channels: arginine-to-histidine mutations affect both functional and protein expression on the cell surface. Biochem J. 2013; 454:259-65. [PubMed: 23734863] 


\section{Highlights}

$\mathrm{KCNC} 3^{\mathrm{R} 420 \mathrm{H}}$ displays aberrant glycosylation $\mathrm{KCNC} 3^{\mathrm{R} 420 \mathrm{H}}$ is retained in the Golgi by immunohistochemistry and FRET Coexpression of $\mathrm{KCNC}^{\mathrm{R} 420 \mathrm{H}}$ and $\mathrm{KCNC} 3^{\mathrm{WT}}$ causes retention of both proteins in the Golgi $\mathrm{KCNC}^{\mathrm{R} 420 \mathrm{H}}$ expression results in Golgi and cell dysmorphology 


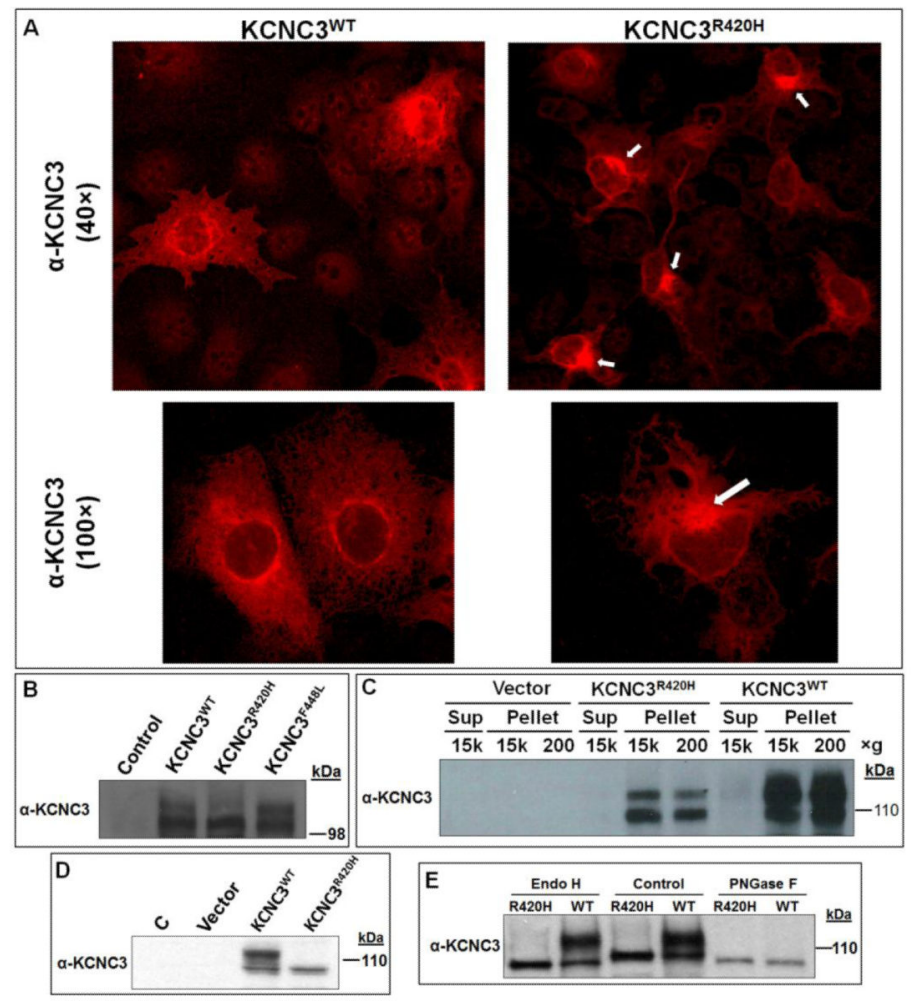

Figure 1. Localization and differential protein modification of $\mathrm{KCNC3}^{\mathrm{WT}}$, $\mathrm{KCNC3}^{\mathrm{F} 448 \mathrm{~L}}$, and $\mathrm{KCNC}^{\mathrm{R} 420 \mathrm{H}}$ in COS-1 and SH-SY5Y cells

(A) OS-1 cells transiently transfected with either $\mathrm{KCNC} 3^{\mathrm{WT}}$ or $\mathrm{KCNC} 3^{\mathrm{R} 420 \mathrm{H}}$ were analyzed by confocal fluorescence microscopy using a KCNC3 antibody. KCNC3 ${ }^{\mathrm{WT}}$ shows perinuclear distribution and punctate staining of plasma membrane whereas $\mathrm{KCNC} 3^{\mathrm{R} 420 \mathrm{H}}$ displays primarily perinuclear staining (white arrows) and very limited fluorescence associated with the plasma membrane. Top and bottom panels were obtained at $40 \times$ and $100 \times$ magnification, respectively. (B) Immunoblot analysis of KCNC3 in COS-1 cells transiently transfected with human $\mathrm{KCNC} 3^{\mathrm{WT}}, \mathrm{KCNC}{ }^{\mathrm{F} 448 \mathrm{~L}}$, or $\mathrm{KCNC}^{\mathrm{R} 420 \mathrm{H}}$ expression vectors illustrates a significant reduction of a slower migrating (upper) band consistent with altered posttranslational modifications. (C) Immunoblot analysis of total protein from COS-1 cells transiently transfected with $\mathrm{KCNC} 3^{\mathrm{WT}}$ or $\mathrm{KCNC} 3^{\mathrm{R} 420 \mathrm{H}}$ subjected to differential centrifugation verifies that there was no fractional loss of the $\mathrm{KCNC} 3^{\mathrm{R}} 420 \mathrm{H}$ protein within our isolation protocol and illustrates the diminished upper band. (D) Immunoblot analysis of KCNC3 in stably transfected human neuroblastoma SH-SY5Y cells illustrating the complete absence of the upper band. (E) Immunoblot analysis of KCNC3 in stably transfected SH-SY5Y cells was used to evaluate the treatment of total protein with Endo $\mathrm{H}$ or PNGase F. The upper band was resistant to Endo $\mathrm{H}$ whereas this species disappeared when total cell extracts were subjected to PNGase F treatment, consistent with the removal of a complex glycan. Both enzymes however led to cleavage of the lower band (control lanes) generating a faster migrating band presumably due to release of a secondary high mannose modification as further illustrated in Figure S1. The removal of a high mannose moiety is consistent with the known activity of Endo $\mathrm{H}$. 


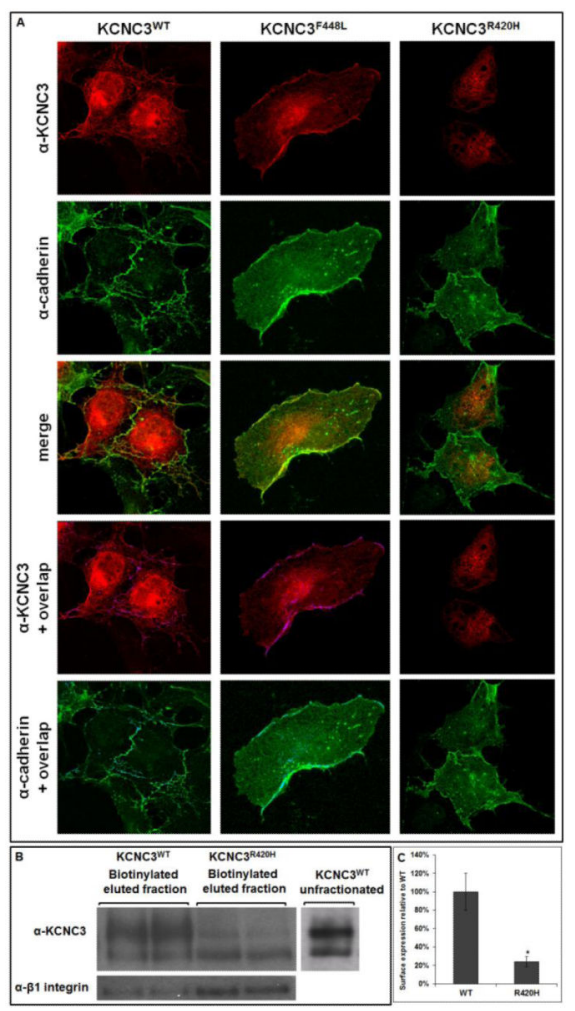

Figure 2. $\mathrm{KCNC3}^{\mathrm{R} 420 \mathrm{H}}$ exhibits limited cell surface expression (A) COS-1 cells transiently transfected with $\mathrm{KCNC} 3^{\mathrm{WT}}, \mathrm{KCNC}^{\mathrm{F} 448 \mathrm{~L}}$, or $\mathrm{KCNC} 3^{\mathrm{R} 420 \mathrm{H}}$ were analyzed by confocal fluorescence microscopy using antibodies to KCNC3 and cadherin as a plasma membrane marker. The top two rows illustrate the images for each antibody in cells expressing $\mathrm{KCNC} 3{ }^{\mathrm{WT}}, \mathrm{KCNC}^{\mathrm{F} 448 \mathrm{~L}}$, or $\mathrm{KCNC}^{\mathrm{R} 420 \mathrm{H}}$. Merged images are provided in the middle row. The bottom two rows illustrate either KCNC3 or cadherin along with overlapping fluorescence illustrated as purple or blue, respectively. $\mathrm{KCNC} 3{ }^{\mathrm{WT}}$ or $\mathrm{KCNC}^{\mathrm{F} 448 \mathrm{~L}}$ showed co-registration with cadherin labeling at the plasma membrane as expected for normal trafficking of an integral membrane protein. (B) COS-1 cells transiently transfected with either $\mathrm{KCNC} 3{ }^{\mathrm{WT}}$ or $\mathrm{KCNC} 3{ }^{\mathrm{R} 420 \mathrm{H}}$ were subjected to surface biotinylation and analyzed by immunoblot to either $\mathrm{KCNC} 3$ or $\beta 1$-integrin as a positive control for surface expression. (C) Corresponding densitometry demonstrates a $76 \%$ reduction in surface expression relative to $\mathrm{KCNC} 3{ }^{\mathrm{WT}}$. Data are presented as mean $\pm \mathrm{SEM}(\mathrm{n}=4)$ and * denotes $\mathrm{p}=0.05$. The lack of any obvious overlap with cadherin staining for $\mathrm{KCNC} 3^{\mathrm{R} 420 \mathrm{H}}$ is consistent with surface biotinylation results demonstrating limited plasma membrane trafficking for this mutant. 


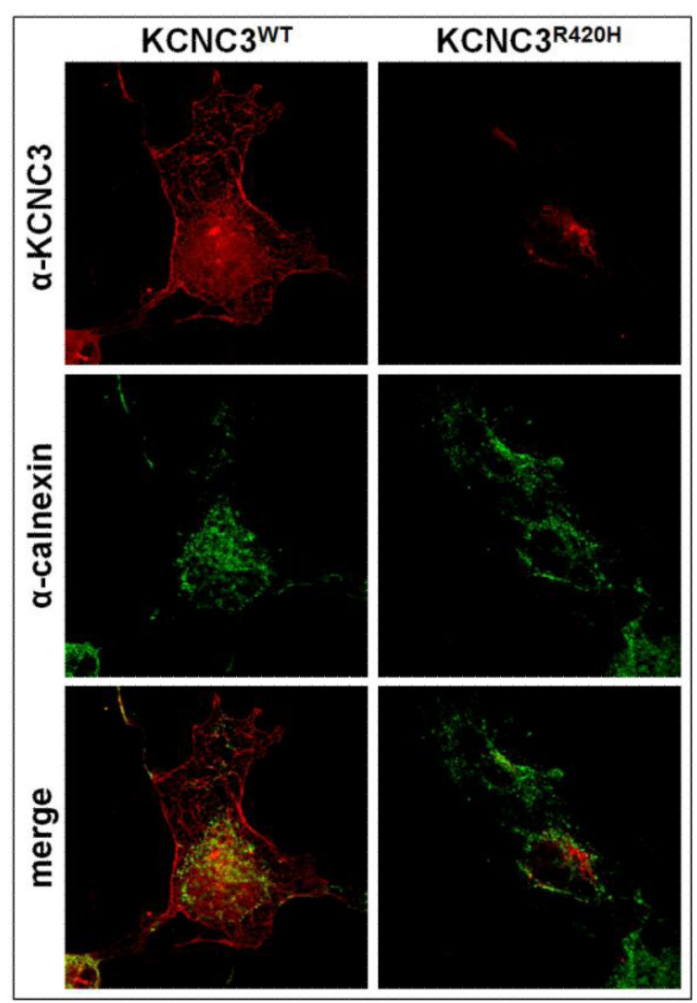

Figure 3. $\mathrm{KCNC}^{\mathrm{R420H}}$ does not co-register with a marker for endoplasmic reticulum (ER) COS- 1 cells transiently transfected with $\mathrm{KCNC} 3^{\mathrm{WT}}$ or $\mathrm{KCNC} 3^{\mathrm{R} 420 \mathrm{H}}$ were analyzed by confocal fluorescence microscopy using antibodies to $\mathrm{KCNC} 3$ and calnexin as a marker for ER. $\mathrm{KCNC}_{3}{ }^{\mathrm{WT}}$ co-registered with calnexin, whereas $\mathrm{KCNC} 3^{\mathrm{R}} 420 \mathrm{H}$ showed no overlap with calnexin. 


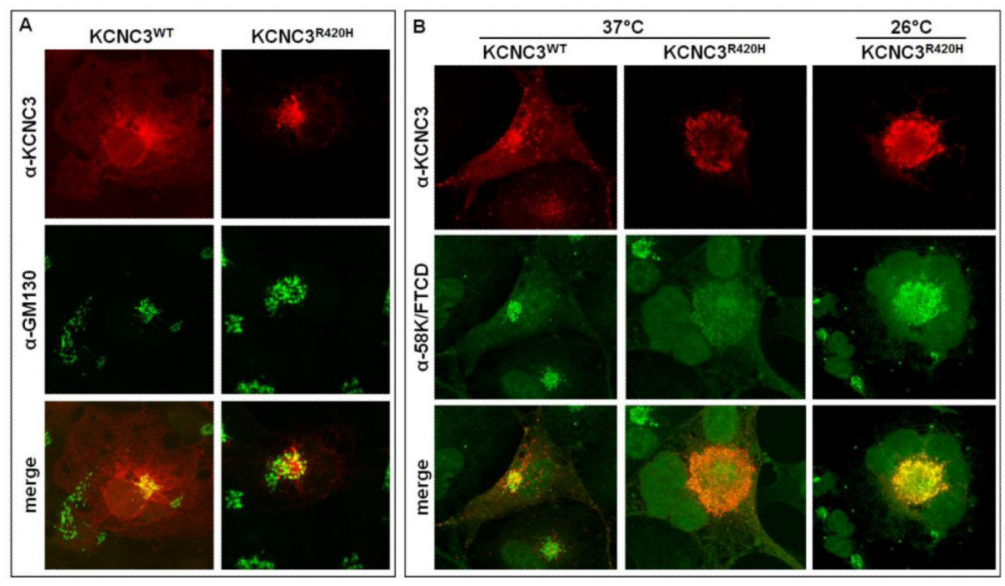

Figure 4. $\mathrm{KCNC3}^{\mathrm{R420H}}$ localization overlaps with Golgi markers

(A) COS-1 cells transiently transfected with $\mathrm{KCNC} 3^{\mathrm{WT}}$ or $\mathrm{KCNC} 3^{\mathrm{R}} 220 \mathrm{H}$ were analyzed by confocal fluorescence microscopy using antibodies to KCNC3 and GM130 (Golgi matrix protein of $130 \mathrm{kDa}$ ), a marker of the cis-Golgi. KCNC3 ${ }^{\mathrm{WT}}$ displayed strong co-registration with the $\mathrm{GM} 130$ whereas $\mathrm{KCNC} 3^{\mathrm{R} 420 \mathrm{H}}$ labeling showed a partial overlap. (B) COS-1 cells transiently transfected with $\mathrm{KCNC} 3^{\mathrm{WT}}$ or $\mathrm{KCNC} 3^{\mathrm{R} 420 \mathrm{H}}$ were grown at $37^{\circ} \mathrm{C}$ and analyzed by confocal fluorescence microscopy using antibodies to KCNC3 and the $58 \mathrm{~K}$ Golgi protein/formiminotransferase cyclodeaminase (58K/FTCD) (first two columns). KCNC3 ${ }^{\mathrm{WT}}$ co-registered with 58K/FTCD also indicative of steady-state trafficking through the Golgi whereas all $\mathrm{KCNC} 3^{\mathrm{R} 420 \mathrm{H}}$ staining completely overlapped with $58 \mathrm{~K} / \mathrm{FTCD}$ demonstrating almost total retention in the Golgi. $\mathrm{KCNC}^{\mathrm{R} 420 \mathrm{H}}$ was also analyzed by growth of transiently transfected COS- 1 cells at $26^{\circ} \mathrm{C}$ to address the effects on rescue of plasma membrane trafficking (third column), with no effect. 


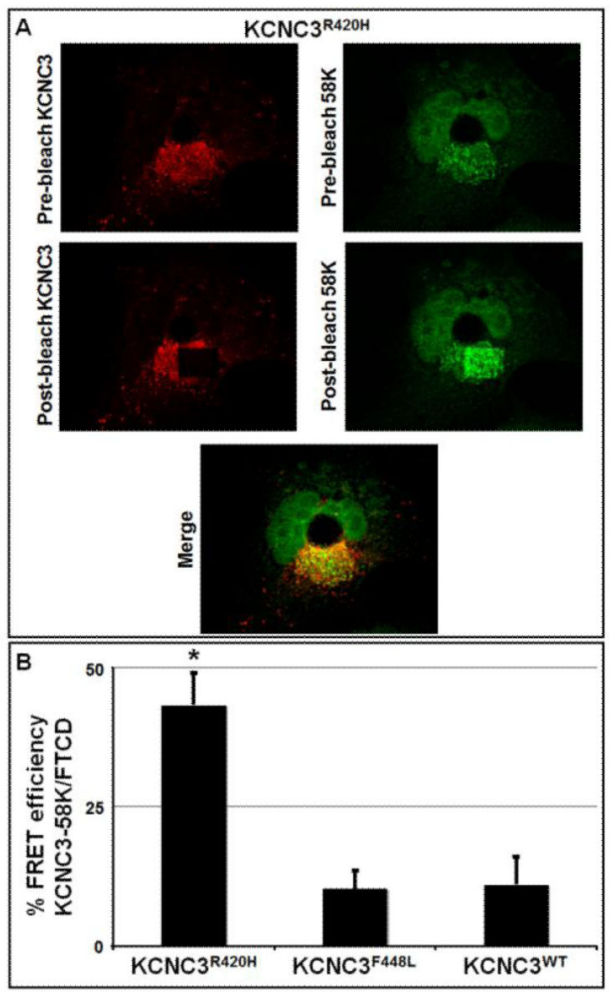

Figure 5. KCNC3 ${ }^{\mathrm{R420H}}$ co-localizes with the Golgi marker $58 \mathrm{~K} / \mathrm{FTCD}$ by acceptor photobleaching FRET (apFRET)

COS- 1 cells were transiently transfected with $\mathrm{KCNC}^{\mathrm{WT}}, \mathrm{KCNC}^{\mathrm{F} 448 \mathrm{~L}}$, or $\mathrm{KCNC}^{\mathrm{R} 420 \mathrm{H}}$. KCNC3 protein was visualized using an antibody conjugated with rhodamine as the acceptor fluorophore, while the 58K/FTCD protein was visualized similarly with FITC. Cells were then analyzed by apFRET. (A) Representative pre-bleach and post-bleach images for $\mathrm{KCNC} 3^{\mathrm{R} 420 \mathrm{H}}$ transfected cells are provided. Images were obtained by laser excitation at $488 \mathrm{~nm}$ (FITC) or $543 \mathrm{~nm}$ (rhodamine). Acceptor bleaching was performed within a region of interest by repeated pulses at $543 \mathrm{~nm}$. (B) Quantitative results are presented as \% FRET efficiency as described in the Materials and Methods. Data are presented as mean \pm SEM $\left(\mathrm{KCNC}^{\mathrm{R} 420 \mathrm{H}}, \mathrm{n}=9 ; \mathrm{KCNC}^{\mathrm{WT}}, \mathrm{n}=8 ; \mathrm{KCNC}^{\mathrm{F} 448 \mathrm{~L}}, \mathrm{n}=6\right)$ and $*$ denotes a $\mathrm{p}=0.05$ of $\mathrm{KCNC}^{\mathrm{R} 420 \mathrm{H}}$ level as compared to $\mathrm{KCNC} 3^{\mathrm{WT}}$. 


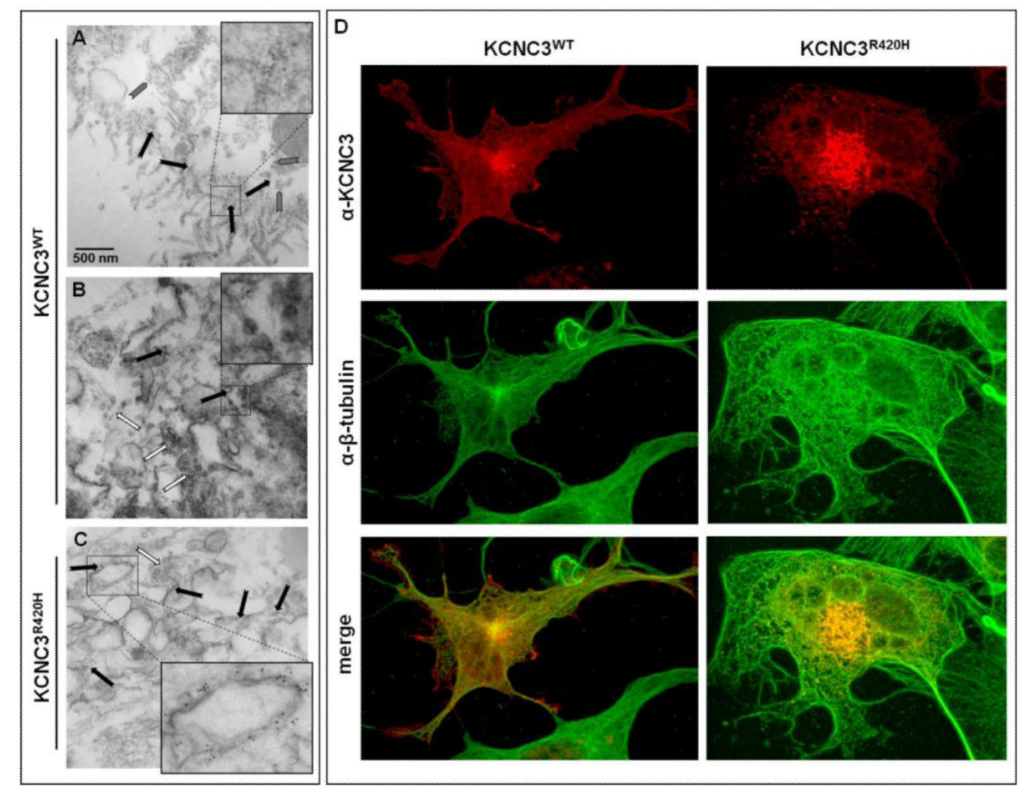

Figure 6. $\mathrm{KCNC}^{\mathrm{R420H}}$ causes alterations in the Golgi apparatus and cellular morphology COS- 1 cells were transiently transfected with $\mathrm{KCNC} 3^{\mathrm{WT}}$ or $\mathrm{KCNC} 3^{\mathrm{R} 420 \mathrm{H}}$ and visualized by immunogold staining of KCNC3 followed by TEM. (A) Black arrows indicate immunogoldstained $\mathrm{KCNC} 3^{\mathrm{WT}}$ near the cell surface with gray arrows denoting $\mathrm{KCNC} 3^{\mathrm{WT}}$ potentially in secretory vesicles. The inset provides an enlarged area containing gold particles. (B) White arrows denote COP (clathrin-ordered protein) vesicles near the Golgi apparatus in the $\mathrm{KCNC} 3{ }^{\mathrm{WT}}$-expressing cells. Black arrows show the limited number of intracellular immunogold-stained $\mathrm{KCNC} 3^{\mathrm{WT}}$ consistent with steady-state trafficking. The inset provides an enlarged area highlighting the COP vesicles. (C) White arrows denote COP vesicles whereas black arrows indicate immunogold-stained $\mathrm{KCNC} 3^{\mathrm{R} 420 \mathrm{H}} \cdot \mathrm{KCNC}^{\mathrm{R} 420 \mathrm{H}}$ concentrates on intracellular membranes associated with what appears to be a dysmorphic Golgi apparatus. The inset provides an example of a swollen Golgi cisternae containing a high level of $\mathrm{KCNC} 3^{\mathrm{R} 420 \mathrm{H}}$ associated with the membrane. (D) COS-1 cells expressing $\mathrm{KCNC} 3^{\mathrm{WT}}$ or $\mathrm{KCNC} 3^{\mathrm{R} 420 \mathrm{H}}$ were examined by confocal fluorescence imaging with antibodies to $\mathrm{KCNC} 3$ and $\beta$-tubulin. $\mathrm{KCNC}^{\mathrm{WT}}$-expressing cells display an ordered tubulin network while $\mathrm{KCNC} 3^{\mathrm{R} 420 \mathrm{H}}$ cells show altered morphology. 


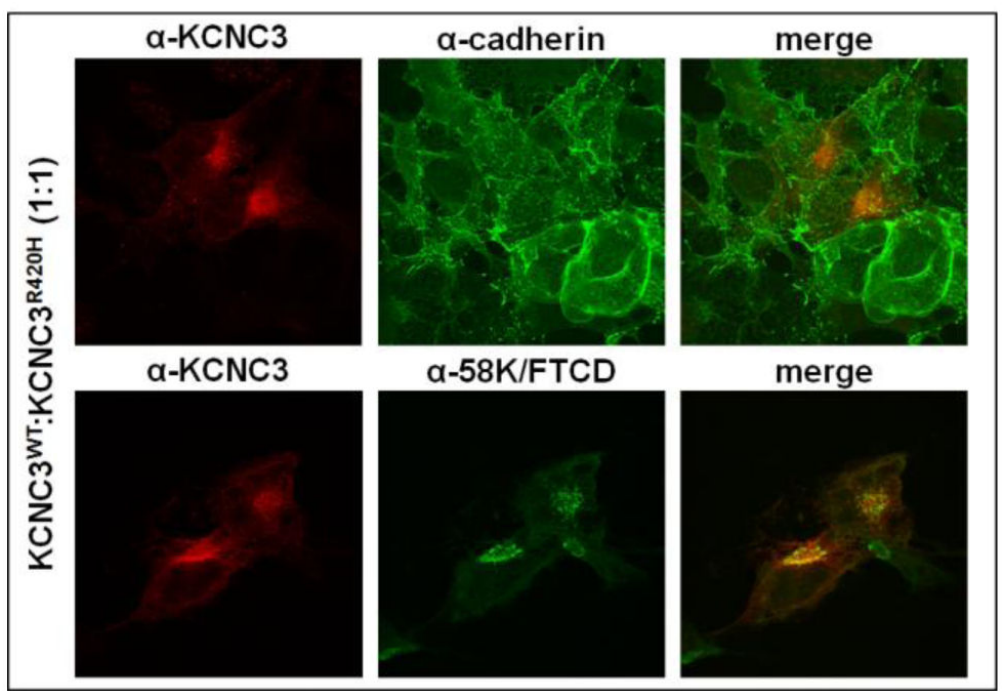

Figure 7. $\mathrm{KCNC3}^{\mathrm{WT}}$ and $\mathrm{KCNC3} 3^{\mathrm{R} 420 \mathrm{H}}$ co-expression leads to Golgi retention and limited cellsurface expression for both proteins

COS-1 cells transiently transfected with $\mathrm{KCNC} 3^{\mathrm{WT}}$ and $\mathrm{KCNC} 3^{\mathrm{R}} 420 \mathrm{H}$ at a $1: 1$ ratio were examined by confocal fluorescence imaging with antibodies to KCNC3 and either cadherin or 58K/FTCD for plasma membrane localization or Golgi retention, respectively. Coexpression of $\mathrm{KCNC}^{\mathrm{WT}}$ and $\mathrm{KCNC}^{\mathrm{R} 420 \mathrm{H}}$ results in limited co-registration of $\mathrm{KCNC} 3$ with cadherin and strong overlap between KCNC3 and 58K/FTCD. 

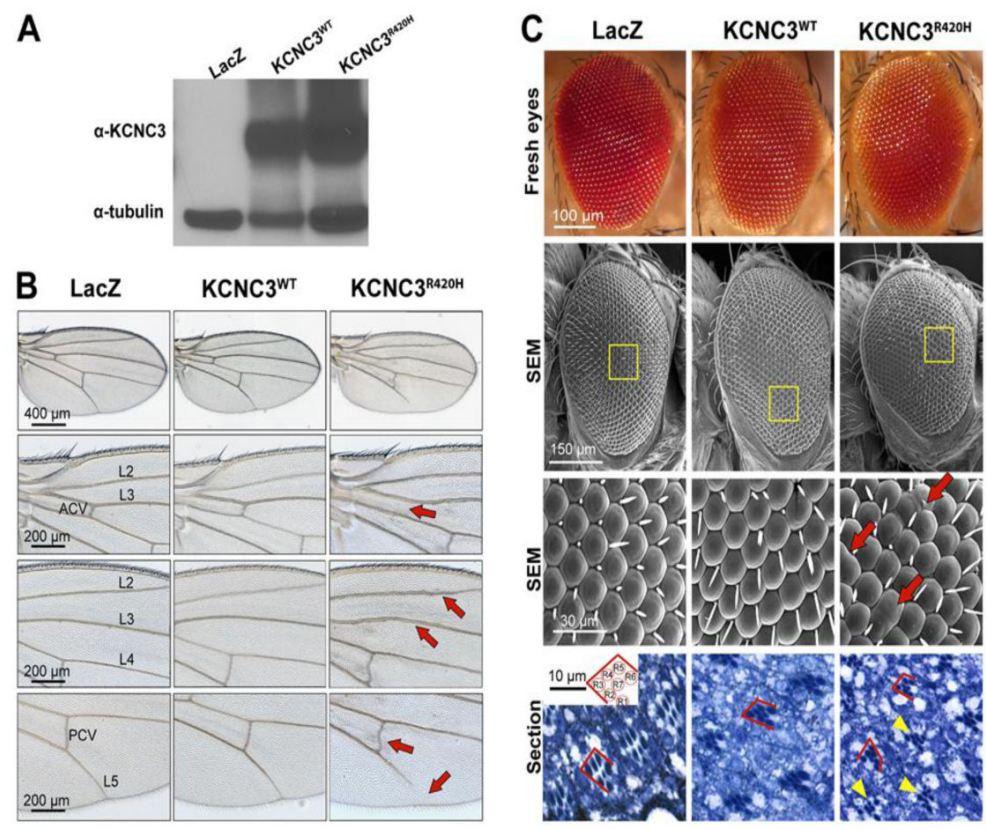

Figure 8. $\mathrm{KCNC}^{\mathrm{R420H}}$ perturbs Drosophila eye and wing morphology

(A) Total protein from a single fly ubiquitously expressing LacZ or human $\mathrm{KCNC}^{\mathrm{WT}}$ or $\mathrm{KCNC} 3^{\mathrm{R} 420 \mathrm{H}}$ as a consequence of crosses with the $d a-G a l 4$ driver (Materials and Methods) was subjected to immunoblot using antibodies against human $\mathrm{KCNC} 3$ and tubulin as a loading control. (B) Wings from da-Gal4 females crossed with $\mathrm{LacZ}$ and $\mathrm{KCNC} 3{ }^{\mathrm{WT}}$ flies show identical wing morphology with perfectly patterned veins. $\mathrm{KCNC}^{\mathrm{R} 420 \mathrm{H}}$-expressing flies show abnormal veins, including loss of the anterior cross vein (ACV), thickening of longitudinal veins L2 and L3, a distorted posterior cross vein (PCV) and partial loss of L5 (red arrows). (C) Images from fresh eyes (top), micrographs from scanning electron microscope (SEM) (middle two rows), and histological sections (bottom) from flies expressing constructs targeted with the eye-specific gmr-Gal4 driver are provided. Higher resolution SEM (third row) are derived from the yellow boxed regions (second row). Eyes from flies expressing $\mathrm{LacZ}$ or $\mathrm{KCNC} 3{ }^{\mathrm{WT}}$ are perfectly organized. Expression of $\mathrm{KCNC} 3^{\mathrm{R} 420 \mathrm{H}}$ resulted in fused ommatidia (red arrows). Toluidine-blue-stained eye sections (bottom row) illustrate the arrangement of photoreceptor cells within each ommatidium. The inset shows the normal geometric organization of photoreceptors in all ommatidia. Eyes from $\mathrm{LacZ}$ and $\mathrm{KCNC} 3^{\mathrm{WT}}$ flies display normal photoreceptor polarity (red lines). $\mathrm{KCNC}^{\mathrm{R} 420 \mathrm{H}}$ eyes contain aberrant differentiation of photoreceptors (yellow arrowheads) and abnormal cell polarity (red lines). 